\title{
Investigation of Sawmill Management and Technology on Waste Reduction at Selected Sawmills in Moratuwa, Sri Lanka
}

\author{
H.T.S. Caldera ${ }^{*}$ and H.S. Amarasekera \\ Department of Forestry and Environmental Science, University of Sri Jayewardenepura, Nugegoda, \\ Sri Lanka
}

Date Received: 14-07-2014 Date Accepted: 25-10-2014

\begin{abstract}
The demand for sawn timber and wood-based products is rising steadily with new developments and the growing domestic consumption in Sri Lanka. Therefore, it is important to strike a balance between the increasing demand and consumption of forest resources. Thus, the key objective of this study was to investigate the effects of sawmill management and technological parameters on loss in conversion from logs to sawn timber and to compare the sawmill efficiency in private sawmills with the state timber corporation sawmill.

Sawmill management and technological parameters were studied in 21 private sawmills and State Timber Corporation sawmill in Kaldemulla to evaluate the effects on loss in conversion. The selected sawmills represent all types available in Sri Lanka, i.e., frame saw, circular saw and band saw mills. Based on the results, mean percentage loss in conversion of teak and mahogany timber for all sawmills (private and State Timber Corporation) in Moratuwa found to be 53.10\%. Significant differences were observed in loss in conversion values between the three categories of private sawmills as well as within sawmills of the same category. It was shown that loss in conversion values also varied with sawmill management and technological parameters such as type of machinery employed, sharpening frequency and sawyer's experience, saw setting, availability of log alignment equipment and saw guards, oversizing and sawn timber sizes.
\end{abstract}

Keywords: sawmill, loss in conversion, waste reduction, mahogany, teak

\section{Introduction}

Forests covered over four billion hectares of land or 30\% of the Earth's land surface globally. In $2005,3.5$ billion $\mathrm{m}^{3}$ of wood of 434 billion $\mathrm{m}^{3}$ of growing stock were removed from the forests where $60 \%$ of this amount was industrial round wood and the rest was fuel wood (Kirilenko and Sedjo, 2007). North America, Asia and Western Europe, are the key suppliers in contributing for the world wood demand (Sandvik, 1999).

As a result of natural forests shrinkage and restrictions on felling and transport there is declining trend in the timber supply from natural forests in Sri Lanka (Amarasekara, 1996). Despite the

\footnotetext{
*Correspondence: savindi.c.@gmail.com

Tel: +61451779663

ISSN 2235-9370 Print/ISSN 2235-9362 Online (C) University of Sri Jayewardenepura
} 
fact that the forest cover is depleting it was forecasted that the demand for sawn wood will grow from 0.544 million $\mathrm{m}^{3}$ in 1993 to 0.885 million $\mathrm{m}^{3}$ in 2020 , showing an increase of about $12,600 \mathrm{~m}^{3} /$ year at an average annual growth rate of $2 \%$ (FSMP,1995).

Sawmilling is a primary industry which provides raw materials to other industries such as construction, joinery, furniture and others. Sawmills can be categorised according to size, machinery and raw materials requirements (Weerawansa and Amarasekera, 1997). Sawing of logs is an essential requirement to their proper and ultimate use and sawmilling plays a significant role in wood utilisation. Substantial amount of total industrial wood products reaches the consumer after sawing (Dwivedi, 1977).

As there is scarcity of raw materials and the level of technology is low, Sri Lankan sawmills are categorised as "small" by world standards. There are number of saw types namely bandsaw, frame saw and circular saw used to breakdown logs and cut into desired sizes of sawn timber. The choice of machinery depends on log resources (species, quality, sizes) financial facilities and available technical knowledge (Blackwell and Walker, 2006).

Awe (2000) describes that the conversion as a measure of sawmill efficiency and it is defined as the percentage volume of sawn timber that can be cut from a given volume of debarked log. Blackwell and Walker (2006) stated that green conversion ranges from 40-65\% in sawmills cutting for grade, which shows a loss in conversion of $35-60 \%$. When considering the waste in converting logs to timber, there are two types such as saw dust and off cuts (Briggs, 1994).

It is apparent that there is a major impact on the loss in conversion during log processing due to factors such as type of wood species, the type of machines employed and the skills and the experience of the operators. The effective utilisation of raw materials amalgamated with skilled labour will lead to effective, efficient and profitable sawmilling (Lundahl, 2007). Nonetheless, the wood waste can be minimised at various points of the log sawing process. If the above factors are taken into account and managed well, sawn wood available to cater the market demand will increase. This will pave the way to reduce the exploitation pressure on the timber resources in Sri Lanka.

The raw material used in sawmills consists of logs which come from different forests which leads to different log characteristics. Smith and Joe (2006) asserted that the timber yield is affected by several $\log$ characteristics such as log diameter, length, taper, eccentricity and sweep. The yield optimisation system can significantly improve timber conversion value in sawmills considering the differences in log characteristics. Badejo (1990) emphasised that, the sizes of log being processed, regardless of the species, have important influence on timber recovery.

Weerawansa and Amarasekera (1997) noted that there is high wastage in the sawmill industry in the western province of Sri Lanka and this research was designed with the purpose of assessing the current situation of the sawmill industry and to conduct a comprehensive study on existing practices on sawmill management and technologies adopted. Therefore, the key objective of the study was to investigate the effects of the sawmill management and technological parameters such as different sawmill machinery, milling characteristics, saw doctoring and sawyers' experience on loss in conversion in sawmills and to compare the sawmill efficiency in private sawmills with the state timber corporation sawmill. 


\section{Methodology}

2.1 Study site
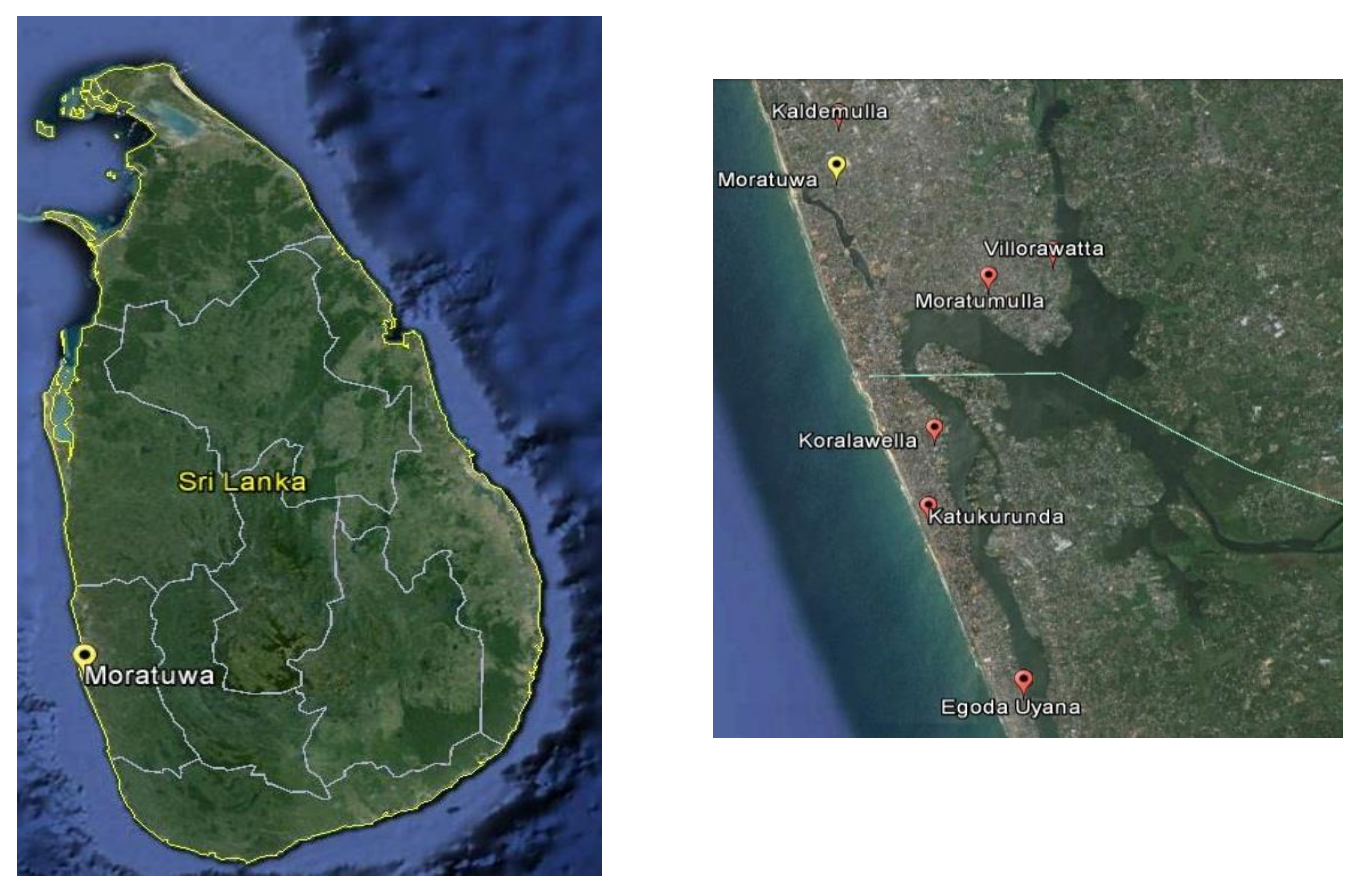

Figure 1: Study site.

Moratuwa area was selected as the study site as it has the highest number of sawmills in the country. Moratuwa is popular for its skilled carpentry work and furniture industry, which provides employment opportunities for many people in that area. Moratuwa town is located in the Colombo District of the Western Province on the Southern direction of City of Colombo. It is bounded by Dehiwala-Mt.Lavinia Municipal Council to the North, Indian ocean to the West and Bolgoda river to the South and to the East. Total extent of the municipal area is approximately $23.4 \mathrm{~km}^{2}$. The Municipal area is divided into 17 wards (Moratuwa Municipal Council, 2002). There are more than 206 registered sawmills distributed throughout the Moratuwa area and $10 \%$ of them was selected for the study.

\subsection{Selection of sawmills}

Stratified random sampling was used to select the samples for the field survey. Sawmills were divided into three categories based on the headrig machine (main saw) employed which were considered as stratums. Samples were randomly selected from different sawmill categories as shown in Table 1. An initial survey was carried out among 45 sawmills in order to decide on the percentage of samples from each category and other related information. A questionnaire was used to interview the sawmill owners and sawmill workers to collect information on sawmill management, technologies utilised, timber species used and to decide on the sampling percentage in the main study. After considering the initial survey results, 21 sawmills were selected for the main study. In addition data were obtained from the State Timber Corporation sawmill located at Kaldemulla to compare the results between government sawmill (STC) and private sawmills. 
Table 1: The distribution of samples.

\begin{tabular}{lcc}
\hline $\begin{array}{l}\text { Type of } \\
\text { headrig }\end{array}$ & No. of sawmills & $\begin{array}{c}\text { Sampling\% calculated from initial } \\
\text { survey }\end{array}$ \\
\hline Frames saw & 12 & $57.14 \%$ \\
Circular saw & 7 & $33.33 \%$ \\
Band saw & 2 & $9.52 \%$ \\
\hline
\end{tabular}

\subsection{Tree species}

Teak (Tectona grandis) and mahogany (Swietenia macrophylla) were the two types of timber species selected for the study. During sampling, logs with minimum visual defects and less curvature were selected.

\subsection{Investigation sawmill management}

Under sawmill management several attributes were studied as given in Table 2.

Table 2: Qualitative data collected in the study.

\begin{tabular}{|c|c|}
\hline Qualitative data & Levels \\
\hline \multirow[t]{3}{*}{ Skill of sawyer } & Sawyer's education level- academic qualifications \\
\hline & Training-Onsite training or National Vocational Qualifications \\
\hline & Experience-number of years working in the sawmilling industry as a sawyer \\
\hline \multirow[t]{3}{*}{ Saw doctoring } & Type of saw setting done \\
\hline & Sharpening frequency \\
\hline & Availability of saw doctoring facility in the sawmill \\
\hline Cutting pattern & Type of cutting pattern (through and through/ cant/ grade/ quarter ) \\
\hline Method of log alignment & Manual or availability of machinery \\
\hline Method of log turning & Manual or availability of machinery \\
\hline Sizes sawn by the sawmills & Different sawn wood products produced and their dimensions \\
\hline $\begin{array}{l}\text { Consistency of the thickness in } \\
\text { the sawn timber and the } \\
\text { cutting marks on the surface }\end{array}$ & $\begin{array}{l}\text { Width measured at different places of sawn timber } \\
\text { Surface texture (appearance- rough/ smooth) }\end{array}$ \\
\hline
\end{tabular}

\subsection{Investigation of sawmill technology}

The type of machinery used in each sawmill were studied to investigate the level of technology. A variety of saws were used progressively to cut the log into timber of the desired dimensions of sawn timber. The measurements that were taken are given in Table 3. Instruments such as measuring tape, diameter tape, vernier caliper, ruler and compass were used to collect data. Saw blade geometry in circular saws were further measured to assess whether loss in conversion varies with tooth pitch, hook angle, clearance angle and tooth height. 
Table 3: Quantitative data collected in the study.

\begin{tabular}{ll}
\hline Quantitative data & Levels \\
\hline Log dimensions & Diameter at bottom $(\mathrm{cm})$ \\
& Diameter at top $(\mathrm{cm})$ \\
& Diameter at middle $(\mathrm{cm})$ \\
& Height $(\mathrm{m})$ \\
Sawn timber dimensions & Width $(\mathrm{cm})$ \\
& Thickness $(\mathrm{cm})$ \\
& Length $(\mathrm{m})$ \\
Saw blade geometry & Tooth height $(\mathrm{cm})$ \\
& Tooth pitch $(\mathrm{cm})$ \\
& Hook angle $\left({ }^{0}\right)$ \\
Milling characteristics & Oversizing $(\mathrm{cm})$ \\
& Blade thickness $(\mathrm{mm})$ \\
& Kerf $(\mathrm{mm})$ \\
\hline
\end{tabular}

\subsection{Calculation of loss in conversion}

Five logs from each species (teak and mahogany) from each sawmill were sampled which accounts to 210 in total. Log length and under bark diameter (top, mid and bottom) of each log were measured. Extremely large logs and small logs were not considered and logs with considerable external visual defects were not sampled to avoid errors. Log volume was calculated using the following formula (Newton's formula) with the values of parameters collected (equation 1). Sawn timber produced by the selected $210 \operatorname{logs}$ was measured immediately after sawing and sawn timber volume was calculated using equation 2. Loss in conversion of each log was calculated as a percentage by using equation 3 (Blackwell \& Walker, 2006) which will provide an indication of the efficiency of the sawmill operations.

$$
\text { Log volume }=\pi L \times \frac{\left(d_{t}^{2}+4 d_{m}^{2}+d_{b}^{2}\right)}{240,000}
$$

where: $\mathrm{L}=\mathrm{Log}$ length

$\mathrm{d}_{\mathrm{t}}=$ Top diameter

$\mathrm{d}_{\mathrm{m}}=$ Mid diameter

$\mathrm{d}_{\mathrm{b}}=$ Bottom diameter

Sawn timber volume $=$ width $\times$ thickness $\times$ length

Loss in conversion $\%=\frac{(\log \text { volume- volume of sawn timber })}{(\log \text { volume })} \times 100$

Data obtained for sawmilling wastage from private sawmills and State Timber Corporation sawmill were computed for both timber species (teak and mahogany) and for different machines. Correlation, regression and Mann-Whitney-U test were used for advance statistical analysis. Furthermore, 1-way-ANOVA was used to test the significance of factors within Turkey's Pairwise Comparison method. 


\section{Results}

\subsection{Sawmill management}

Number of sawyers and educational levels

Results showed that the number of workers employed in sawmills varied from 2 to 7 . The main sawyer was responsible to feed the log to the headrig while others assist him in it and do their tasks in edging, cross cutting and other auxiliary processes in sawn timber production.

\section{Sawyers educational level and training}

All sawyers interviewed have studied up to grade 8 or GCE ordinary level in secondary education and none of the sawyers have pursued up to GCE advance level examination. Sawyers of the State Timber Corporation which accounts for 5\% of total sawyers received training on sawmilling and saw doctoring from Timber Technology Training Institute. All sawyers work in private sawmills did not receive any specific skill training but have undergone onsite training where they have learned through experience.

\section{Saw setting in sawmills}

Out of the 22 sawmills sampled, $68 \%$ used spring setting as the saw setting technique while $32 \%$ adopted swage setting. It was observed that the swage-set tooth points have less opportunity of sideways deflection whereas with spring-set teeth have is a gap between one side and the timber. Carbide tips were observed in all circular sawmills in Moratuwa where they adopted swage setting.

\section{Log turning, log alignment and cutting pattern}

Log turning and log alignment in all sawmills were manually done and hence the productivity of these operations depend on the proficiency of the sawyer in terms of knowledge and skill in checking for wood defects and deciding cutting patterns to produce maximum volume of sawn timber. It was observed that the main sawyer is responsible for feeding the log into the headrig where some of them have developed that skill of log alignment, checking for the "crack directions from the pith" and feed the log perpendicular to that to minimise the effects of the crack in the sawn timber. All sawmills followed the through and through cutting pattern which is frequently used for sawing planks.

\section{Log storage, sawmill housekeeping and utilisation of wood waste}

Most sawmills stored logs in an adjacent land to sawmill. However, there were no special measures taken to protect logs in the log yard. Green logs and sawn timber were just laid on the ground without proper stacking and was exposed to insects, fungi and weather changes. Poor housekeeping was observed in sawmills as sawdust and wood parts were lying haphazardly. 18 sawmills sell the collected sawdust and off cuts to buyers who use them for boilers, to manufacture briquettes and off cuts to produce small furniture such as toys and for wood composite industry. STC sawmill provide some amount of sawdust for free of charge to local community to use as fuel. The rest of sawmills dispose the sawdust to a dump yard or nearby water source close by creating environmental issues.

\subsection{Milling characteristics}

The mean diameter in middle of the mahogany log sample (105 logs) was $34.5 \mathrm{~cm}$ and the mean mid diameter of the teak log sample $(105 \operatorname{logs})$ was $34.2 \mathrm{~cm}$ and the mean log length of the $210 \operatorname{logs}$ was $3.3 \mathrm{~m}$. Through the interview, it was revealed that sawmills produce oversized timber accommodating planning allowance and shrinkage allowance. Results showed that $62 \%$ of sawmills use oversizing of $(0.32 \mathrm{~cm})$ while a $14 \%$ of sawmills use an oversizing of $(0.48 \mathrm{~cm})$. 
Diameter and length of timber species sampled from private sawmills

Figure 1 illustrates the relationship between log length and loss in conversion. The line shows an increasing trend with the increase in log length. There was a significant correlation between these two variables.

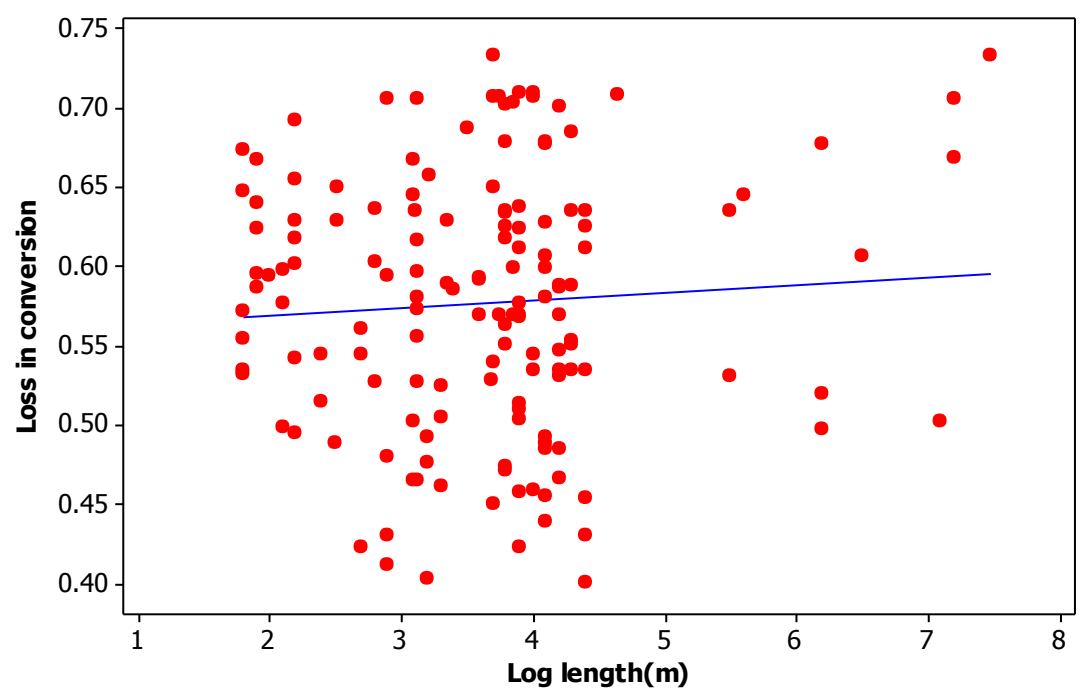

Figure 1: Variation of loss in conversion with log length.

Figure 2 shows the relationship between log mid diameter and loss in conversion which shows a decreasing trend with the increase in mid diameter of logs. The correlation between these two variables was significant.

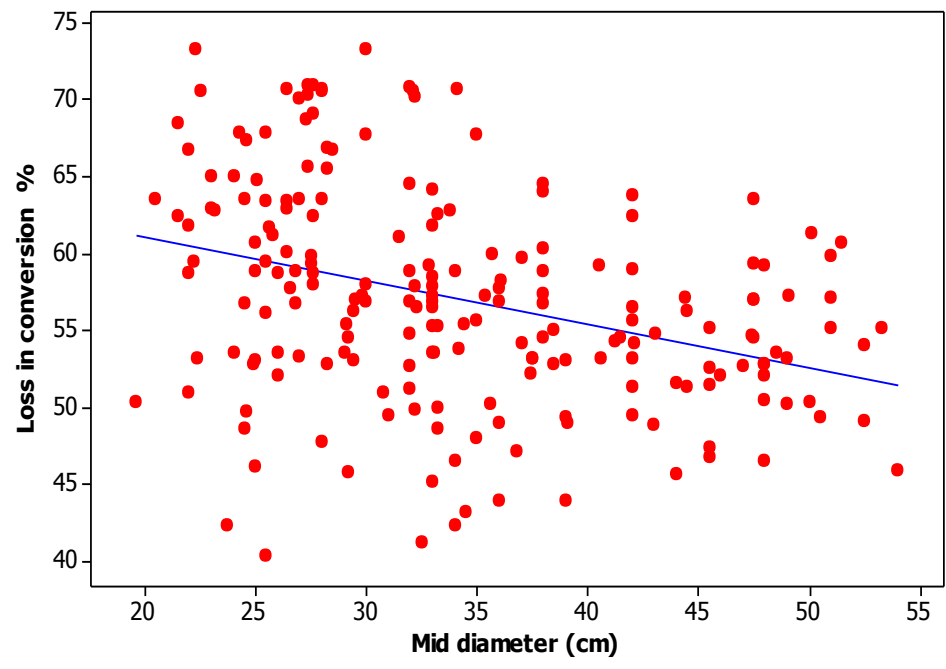

Figure 2: Variation of loss in conversion with the mid diameter of logs.

\subsection{Loss in conversion in private sawmills}

Mean percentage loss in conversion of private sawmills in Moratuwa was 56.9\% (conversion of 43.1\%). The highest average loss in conversion value was observed in inserted tooth circular sawmill. The lowest average loss in conversion was showed in band sawmill. The effects of various factors on loss in conversion are described in the following section. 
Effect of the type of machinery and timber species on loss in conversion

The results in table 5 showed the mean loss in conversion\% values. The highest mean loss in conversion was shown in the inserted tooth circular saw for mahogany and teak recorded mean loss in conversion values of $65.05 \%$ and $63.77 \%$ respectively. The lowest mean loss in conversion was shown when timber was sawn by band saw which was $45.19 \%$ and $46.75 \%$ for mahogany and teak respectively.

Table 5: Results of ANOVA test carried out for mean loss in conversion between sawmill type and timber species.

\begin{tabular}{lccc}
\hline $\begin{array}{l}\text { Machine/ } \\
\text { Species }\end{array}$ & Mahogany \% & Teak \% & $\begin{array}{c}\text { Mean loss in } \\
\text { conversion \% }\end{array}$ \\
\hline Band & 45.19 & 46.75 & 45.97 \\
Circular & 65.05 & 63.77 & 64.41 \\
Frame & 54.03 & 54.66 & 54.34 \\
\hline
\end{tabular}

One-way ANOVA tests conducted between sawmill types for mahogany timber species indicated significant results (Table 6). This indicated a significant difference between loss in conversion values of band, circular and frame saw when sawing mahogany. Similarly the results were significant for teak as well. This indicates that the sawmill technology or the machinery deployed have caused a variation of loss in conversion.

Table 6: Results of ANOVA test carried out for mean loss in conversion within sawmill type.

\begin{tabular}{llcc}
\hline Timber type & Sawmill type & P value & Significance \\
\hline Teak & Frame saw & 0.000 & significant \\
& Circular saw & 0.004 & significant \\
& Band saw & 0.029 & significant \\
Mahogany & Frame saw & 0.000 & significant \\
& Circular saw & 0.004 & significant \\
& Band saw & 0.029 & significant \\
\hline
\end{tabular}

Table 7 shows the mean loss in conversion values of private and STC sawmills which used a bandsaw for headrig. Mean loss in conversion values of mahogany and teak species were lower in private sawmills when compared to STC sawmill.

Table 7: Mean loss in conversion of private sawmills and STC.

\begin{tabular}{lcc}
\hline Species & Private sawmills\% & STC sawmill\% \\
\hline Mahogany & $45.88(\mathrm{SD}=0.31)$ & $46.74(\mathrm{SD}=0.03)$ \\
Teak & $42.35(\mathrm{SD}=0.14)$ & $52.04(\mathrm{SD}=0.08)$ \\
\hline
\end{tabular}

Mean loss in conversion value of teak in STC was higher than that of private sawmills as STC remains the sapwood while private sawmills utilise it. However, Mann-Whitney U test did not show significant difference between the mean loss in conversion values between STC sawmill and private band sawmills. 


\section{Effect of blade thickness on loss in conversion}

Figure 3 illustrates the variation of loss in conversion with the blade thickness. The highest mean loss in conversion was observed when the blade thickness was $4.19 \mathrm{~mm}$ whilst the lowest mean loss in conversion value was observed when the blade thickness was $1.24 \mathrm{~mm}$. Mean loss in conversion increased with the increase in blade thickness. It can be observed that the blade thickness varied in the different machineries which caused variation of loss in conversion. A significant correlation also proved the effect of blade thickness in loss of conversion.

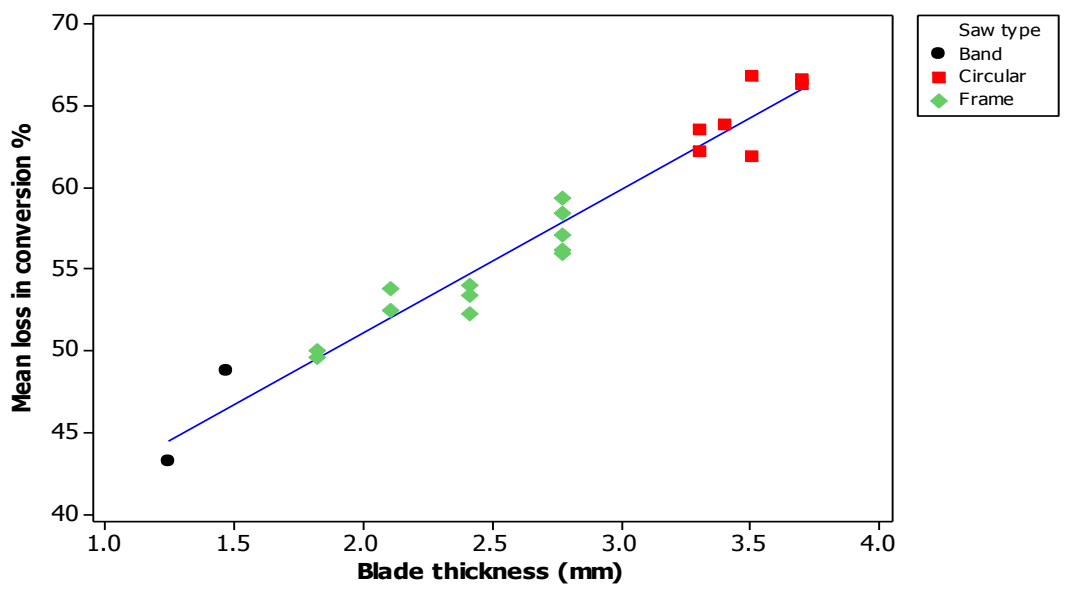

Figure 3: Variation of mean loss in conversion for different blade thickness.

\section{Effect of kerf on loss in conversion}

Figure 4 illustrates the variation of loss in conversion with kerf which is a parameter measured under milling characteristics. Mean loss in conversion increased with the increase in kerf. The highest mean loss in conversion was observed when the kerf was $4.50 \mathrm{~mm}$ whilst the lowest mean loss in conversion value was observed when the kerf was $2.2 \mathrm{~mm}$. Therefore, if the kerf is low a lower loss in conversion is occurred.

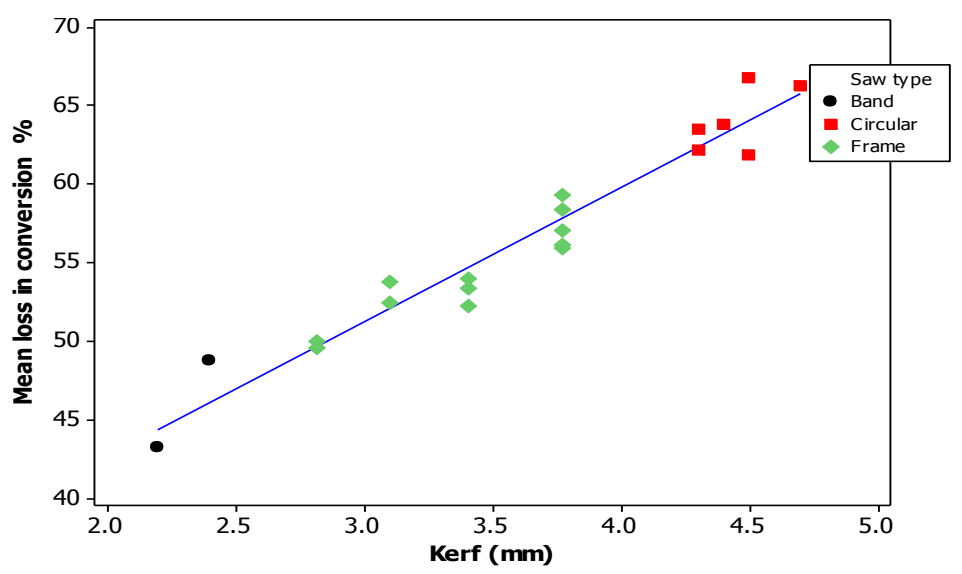

Figure 4: Variation of mean loss in conversion with different kerf.

Effect of circular saw geometry on loss in conversion

A positive correlation was observed between tooth height and loss in conversion whereas a negative correlation was shown between the hook angle and the tooth pitch and the loss in conversion 
(Table 8). When the tooth height increases further after a certain level it generates more saw dust during cutting and increases the loss in conversion as the gullet area gets expanded.

Table 8: Inserted tooth circular saw geometry.

\begin{tabular}{ccccc}
\hline Sawmill & $\begin{array}{c}\text { Tooth pitch } \\
(\mathrm{cm})\end{array}$ & $\begin{array}{c}\text { Hook angle } \\
\left({ }^{\circ}\right)\end{array}$ & $\begin{array}{c}\text { Tooth height } \\
(\mathrm{cm})\end{array}$ & $\begin{array}{c}\text { Mean loss in } \\
\text { conversion } \%\end{array}$ \\
\hline C1 & 7.3 & 30 & 5.7 & 63.46 \\
C2 & 9.5 & 35 & 4.1 & 62.13 \\
C3 & 7.2 & 30 & 5.9 & 66.80 \\
C4 & 7.8 & 30 & 6.2 & 66.26 \\
C5 & 9.4 & 35 & 4.0 & 61.86 \\
C6 & 7.5 & 30 & 6.0 & 66.57 \\
\hline
\end{tabular}

Effect of sawyer's experience on loss in conversion

Figure 5 showed the variation of mean loss in conversion with the sawyer's experience in number of years. There is a decreasing trend of mean loss in conversion with the increase sawyer's experience.

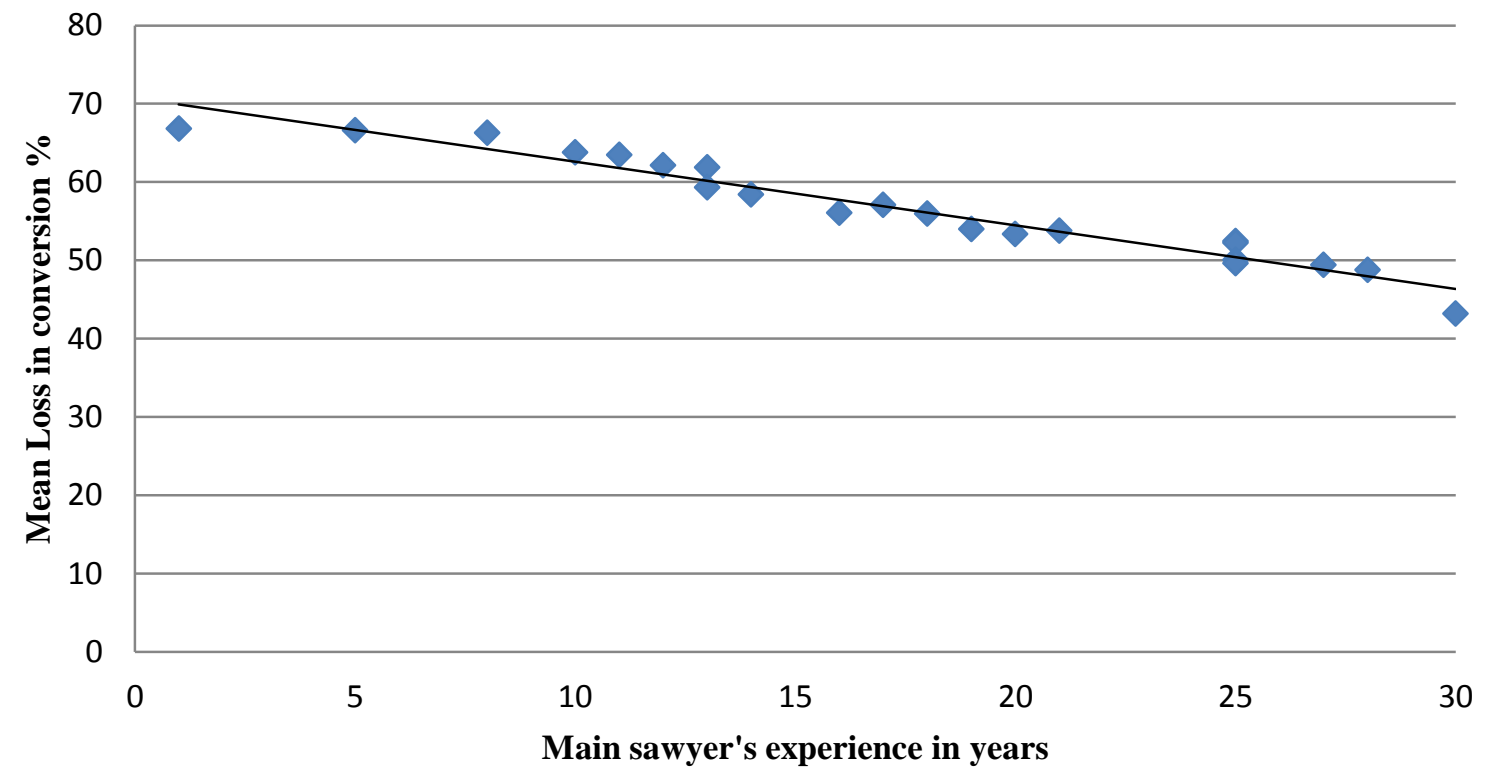

Figure 5: Variation of loss in conversion with sawyer's experience.

\section{Discussion}

The present study was based on assessing effects of sawmill management and technological parameters on loss in conversion, which provides an indication on the level of sawmill efficiency. The calculations were carried out using the method described by Blackwell and Walker (2006) taking log volume and sawn timber volume into consideration. Based on the results, the average percentage loss in conversion of teak and mahogany timber for all sawmills (private and STC) in Moratuwa is $53.10 \%$ (conversion 46.9\%) which is within the green conversion range of 40-65\% in sawmills cutting for grade suggested by Blackwell and Walker (2006). 
Loss in conversion values between the three sawmill categories varied at a statistically significant level. Under the private sawmills the highest wastage was observed in inserted tooth circular saw which recorded a mean loss in conversion value of $64.4 \%$. This can be caused by using thick tungsten carbide tipped blades used in those sawmills. Weerawansa and Amarasekera (1997) stated the most wasteful machine was inserted tooth circular saw which was proved in the current study as well. The difference in gauge of the carbide tips can also cause the variation of the saw dust generated and the volume of the solid wood waste (slabs) produced. As saw guards were unavailable in most circular sawmills, it led to disorient the log as the machine vibrates and results in crooked cuts and inconsistent planks. Moreover the surface texture is irregular and rough when timber is sawn using inserted tooth circular saw.

Percentage loss in conversion values were relatively low in frame saw and band saw which were $54.3 \%$ and $46.0 \%$ respectively. The lowest loss in conversion showed in band sawmills can be attributed to thin flexible cutting blades employed in those mills. Steele (1984) also showed that band sawing which use a thinner blade cut drastically changes the yield.

A high loss in conversion can be caused by to circular saw machine deployed, lack of experienced sawyers, poor skills in log turning and log alignment, excess oversizing and poor saw doctoring. In converse the lowest mean loss in conversion in band sawmills can be attributed to band saw machine used, experienced sawyers and effective sawmill management. For the variation in loss in conversion values within the same sawmill category can be attributed to sawyer's level of education, training, experience, the state of saw doctoring (saw sharpening and maintenance), skill in log alignment and log turning, and milling characteristics such as oversizing, product sizes sawn and kerf. The difference in gauge (blade thickness) of the carbide tips in inserted tooth circular saw and the variation in blade thickness of frame and band saw can also cause the deviation of the saw dust generated and the volume of the solid wood waste (slabs) produced in sawmills with in the same category.

The results show that the loss in conversion increased with the increased blade thickness and kerf. Kukogho et al (2011) also found saw kerf is directly proportional to the volume of sawdust produced during sawing. Results revealed that band saws have thinner blade thickness and kerf compared to circular saw. Bratkovich (1996) also stated when circular saws are compared to band saws, then band saws would be considered higher gauge (lower blade thickness). It was observed that when the hook angle increases and the tooth it has a tendency to wear off and break. Tooth geometry is subject to a number of interactions. Walker (2006) also states that increasing the hook angle and reducing the sharpness of tooth will affect the tooth to wear faster and is more likely to break. According to the primary log data gathered, some logs with similar dimensions had different loss in conversion values, which could be attributed to the grade of the timber. Grade is assessed by the nature and number log defects which reflects the quality of the timber. Therefore the timber grade has an impact on the recovery of the sawn timber.

\section{Conclusion}

It was shown that loss in conversion values varied with sawmill management and technological parameters such as type of machinery employed, sharpening frequency and sawyer's experience. Furthermore loss in conversion can be affected by saw setting, availability of log alignment equipment and saw guards, oversizing and sawn timber sizes as well. Therefore, the loss in conversion in sawmilling is determined by an interaction of several factors. 
The results depicted that the blade thickness significantly affect the loss in conversion value. High wastage was caused by using thick tungsten carbide tipped blades used these saw sawmills. In contrast lowest loss in conversion was showed in band sawmills with thin flexible cutting blades. It is important to replace obsolete machinery with new technology to reduce wood waste in form of sawdust. Upgrading of machinery can be done by means of using thin kerf saws and hence band saw can be recommended. In order to saw denser species band saws with tungsten carbide tips can be proposed. Through the interviews it was revealed that there is an issue of metal wires and particles inside the logs hindering the functioning of the saw, a metal detector or a scanning device will be conducive for detecting the presence of metal parts in the log.

\section{References}

Amarasekara, H. 1996. Selecting alternatives in place of naturally grown timber species. Local timbers for future, 49-52.

Awe, O.A. 2000. Assessment of wood conversion efficiency in some sawmills in Ondo State, Unpublished ND project, Federal College of Forestry, Jericho, Ibadan.

Badejo, S.O. 1990. Sawdust utilization for building material manufacturing in Nigeria, Technical Report, Forestry Research Institute of Nigeria, Ibadan, January, 2001.

Blackwell, P. and Walker, J.C. 2006.Sawmilling in primary wood processing. Springer, Netherlands.

Bratkovich, S. 1996. Thin kerf sawing: A technology worth adopting, USDA Forest Service, Northeastern Area State \& Private Forestry.

Briggs, D.G. 1994. Forest products measurements and conversion factors: With special emphasis on the US Pacific Northwest. College of Forest Resources, University of Washington, Seattle.

Dwivedi, A. 1977.Handbook of saw milling.

FSMP. 1995. Forestry Sector Master Plan, Forest Resources Development Division, Ministry of Agriculture, Lands and Forestry.

Kirilenko, A.P. and Sedjo, R.A. 2007. Climate change impacts on forestry. Proceedings of the National Academy of Sciences, 104(50): 19697-19702.

Kukogho, J., Aghimien, E., Ojo, M., Adams, B. and Akinbosoye, B. 2011. Assessment of wood waste generated in some selected sawmills in Kajola local government area of Oyo state. Continental Journal of Agricultural Economics, 5(2).

Lundahl, C.G. (2007). Optimized processes in sawmills: Luleå tekniska universitet/LTU Skellefteå/Träteknologi.

Moratuwa Municipal Council, 2002.City profile, http://www.unhabiat.lkdownload/SCP/Moratuwa.pdf.

Sandvik, A.B. 1999. The handbook of production use and maintainace of wood bandsaw blades. Sandvik Coromant, Sweden.

Smith, A.J. and Joe, B. 2006.Factorsdetermining lumber recovery in sawmilling. National Board of Vocational Education, Forestry Training Programme for Developing Countries, Helsinki, Finland.

Steele, P.H. (1984). Factors Determining Lumber Recovery in Sawmilling. Retrieved from http://oai.dtic.mil/oai/oai?verb=getRecord\&metadataPrefix=html\&identifier=ADA142080

Walker, J.C. (2006). Primary wood processing: principles and practice. Springer Science and Business Media.

Weerawansa, P.S. and Amarasekera, H.S. 1997. Evaluation of the sawmilling wastage of sawmills in western province of Sri Lanka, Proceedings of the $3^{\text {rd }}$ Annual Forestry Symposium of the Department of Forestry and Environmental Science, University of Sri Jayewardenepura, Sri Lanka. 